\title{
Availability, prices and affordability of the World Health Organization's essential medicines for children in Guatemala
}

\author{
Angela Anson ${ }^{1 *}{ }^{*}$, Brooke Ramay $^{2 \dagger}$, Antonio Ruiz de Esparza ${ }^{3}$ and Lisa Bero ${ }^{4}$
}

\begin{abstract}
Background: Several World Health Organization (WHO) initiatives aim to improve the accessibility of safe and effective medicines for children. A first step in achieving this goal is to obtain a baseline measure of access to essential medicines. The objective of this project was to measure the availability, prices, and affordability of children's medicines in Guatemala.
\end{abstract}

Methods: An adaption of the standardized methodology developed by the World Health Organization and Health Action International (HAl) was used to conduct a cross sectional survey to collect data on availability and final patient prices of medicines in public and private sector medicine outlets during April and May of 2010.

Results: A subset of the public sector, Programa de Accesibilidad a los Medicamentos (PROAM), had the lowest average availability (25\%) compared to the private sector (35\%). In the private sector, highest and lowest priced medicines were 22.7 and 10.7 times more expensive than their international reference price comparison.

Treatments were generally unaffordable, costing as much as 15 days wages for a course of ceftriaxone.

Conclusions: Analysis of the procurement, supply and distribution of specific medicines is needed to determine reasons for lack of availability. Improvements to accessibility could be made by developing an essential medicines list for children and including these medicines in national purchasing lists.

Keywords: Guatemala, Essential medicines for children, National formulary, Availability, World Health Organization

\section{Background}

Children in poorer countries are more likely to die from treatable conditions than those in higher resource settings because they do not receive appropriate or timely medications [1]. This is also true in Guatemala, where poverty contributes to the country's high mortality rate for children under the age of five [2]. Millennium Development Goal 4 (MDG4) states that a two-thirds reduction in mortality from 1990 to 2015 in children younger than five years is essential for global development [3]. Compared to the rate of mortality in 1990, Guatemala will need to increase the rate of decline in childhood deaths from 75.8 to 25.3 deaths per 1000 to achieve the MDG goal by 2015 [4]. To assist member countries with achieving MDG4,

\footnotetext{
* Correspondence: anganson21@gmail.com

'Equal contributors

'Department of Clinical Pharmacy, University of California, San Francisco, CA 94143-0622, USA

Full list of author information is available at the end of the article
}

the WHO constructed the first Essential Medicines List for Children (EMLc) and launched the "Make Medicines Child Size" effort in December of 2007. This initiative aims to improve the accessibility of safe, effective and quality medicines for children by promoting awareness and action through research, regulatory measures and changes in government policy.

A vital first step to improving medicine access for children is measuring the availability and prices of essential medicines present on pharmacy shelves and in national medicines lists. Data on medicine stock deficits and unaffordable prices creates an evidence base to inform the development of national and regional policies. A recent survey of essential medicines for children in Africa exposed the severe lack of medicines for children in central medicine stores, hospitals, pharmacies and national medicine lists in 14 different countries [5]. The objective of this study is to measure access to children's medicines 
in Guatemala using validated methods, similar to those used in Africa [6,7].

\section{Sources of medicines in Guatemala}

The Ministry of Health network is a publically funded group of primary, secondary and tertiary healthcare centers that render services to approximately $70 \%$ of the population in Guatemala [8]. Tertiary care hospitals provide a variety of medical specialty and outpatient services and offer medicines on an inpatient basis only, free of charge. The proportion of families who utilize these services or seek treatment elsewhere to care for their sick children is unknown.

The Ministry of Health also operates PROAM, which are pharmacies that offer medicines from Lista Basica, a formulary of medicines for common diseases afflicting the population. PROAM was created in 1998 by the Guatemalan Ministry of Health to ensure equal access to quality medications at reasonable prices [9]. The Ministry of Health establishes "contrato abierto", a system for setting suppliers and prices in which the government negotiates contracts with pharmaceutical companies to purchase medications [10,11]. The government then distributes medicines from Lista Basica needed to stock PROAM pharmacies which are subsequently sold to consumers. PROAM consists of approximately 514 outpatient medicine outlets throughout the country [12]. The law requires that all medications sold must comply with the United States pharmacopeia XXIV quality standards.

The most numerous medicine outlets in Guatemala are privately owned pharmacies, which number close to 4043 establishments throughout the country [12]. This makes the private sector an important source of medicines in Guatemala. There are various laws governing the structure and sanitation of all pharmacies, but no laws regulate the acquisition or prices of medications in the private sector [13-15]. Other sources of medication in Guatemala include Social Security hospitals, private hospitals, dispensing doctors, non-governmental organizations (NGOs) and unregistered dispensaries.

\section{Methods}

We conducted a survey of the availability, prices and affordability of children's medicines in Guatemala using an adaption of the standardized methodology developed by the World Health Organization (WHO) and Health Action International (HAI) [7]. A validation study of the WHO/HAI survey methodology conducted in Peru in 2005 found that focusing on commonly used medicines yields sufficient and valid results [16]. We collected data on the availability and final patient prices of medicines in a subsector of public and private sector medicine outlets during April and May of 2010.

\section{Selection of medicine outlets}

We selected six regions as survey areas for data collection: Guatemala City, Escuintla, Jalapa, Quetzaltenango, Retalhuleu, and Alta Verapaz. The major urban center of Guatemala City was selected and an additional five "departamentos" or states were chosen at random from those which could be reached within a day's travel from Guatemala City. These departamentos are all comprised of a collection of urban and rural areas, however, the actual survey areas within each departamento varied demographically.

In each survey area, four to seven private and PROAM sector medicine outlets were randomly selected from a list of pharmacies registered by the Ministry of Health. The actual number surveyed was limited by accuracy of the Ministry of Health registry list and available manpower to carry out the surveys. The private sector sample included 29 outlets and the PROAM sector included 21 outlets. A tertiary public hospital located in each survey area was also included when permission was granted, yielding a sample of four hospitals. Pharmaceutical stores held by private dispensing doctors and nongovernmental organizations were not surveyed due to lack of time and resources.

\section{Selection of medicines}

The "Better Medicines for Children Project" specifies a core list of the EMLc to be surveyed, representing medicines commonly used in the treatment of a range of conditions associated with childhood illness prevalent in low income countries [6]. The list specifies the child-specific dosage form and strength for 23 medicines, as well as one device.

We included 22 medicines and one device from the core list in the Guatemala survey. Artemether + lumefantrine was excluded, as it is used for P. falciparum species of malaria, which is not common in the Americas. Primaquine was selected as an alternate malarial medication, as it is effective against P. vivax, the prevalent species of malaria in Guatemala. When alternate formulations were registered in Guatemala, these were added into the list of index medicines and surveyed. In total, 27 medicines and one device were surveyed in Guatemala (Table 1).

For each medicine surveyed, we recorded the highest and lowest price medicine available. In the PROAM sector, manufacturer was also recorded to determine if the product was brand or generic. Medicines in the public hospitals were free of charge to hospitalized patients so only availability was measured.

\section{Data collection and analysis}

Data collection took place during April and May of 2010. Six data collectors were trained according to the WHO/ HAI methodology and pilot data collection was conducted. The data collectors visited medicine outlets and collected 
Table 1 List of medicines surveyed in Guatemala

\begin{tabular}{|c|c|c|c|c|}
\hline No. & Disease & Name & Strength & Dosage form \\
\hline 1 & Asthma & Salbutamol* & $100 \mathrm{mcg} /$ dose & Inhaler \\
\hline 2 & Asthma & Beclomethasone & 100 mcg/dose & Inhaler \\
\hline 3 & Dehydration & Zinc & $20 \mathrm{mg}$ & Dispersible tab \\
\hline 4 & Dehydration & Oral Rehydration Solution & $500 \mathrm{ml}$ & Solution \\
\hline 5 & Dehydration & Oral Rehydration Solution, powder* & To make $500 \mathrm{ml}$ & Powder \\
\hline 6 & Infectious disease & Amoxicillin & $100 \mathrm{mg} / \mathrm{ml}$ & Pediatric drops \\
\hline 7 & Infectious disease & Amoxicillin & $125 \mathrm{mg} / 5 \mathrm{ml}$ & Suspension \\
\hline 8 & Infectious disease & Amoxicillin* & $250 \mathrm{mg} / 5 \mathrm{ml}$ & Suspension \\
\hline 9 & Infectious disease & Amoxicillin + Clavulanic Acid & $125 \mathrm{mg}+31.25 \mathrm{mg} / 5 \mathrm{ml}$ & Suspension \\
\hline 10 & Infectious disease & Amoxicillin + Clavulanic Acid* & $250 \mathrm{mg}+62.5 \mathrm{mg} / 5 \mathrm{ml}$ & Suspension \\
\hline 11 & Infectious disease & Benzathine Penicillin $\mathrm{G}^{*}$ & $1.2 \mathrm{M}$ units/vial & Injection \\
\hline 12 & Infectious disease & Ceftriaxone* $^{*}$ & $500 \mathrm{mg} / \mathrm{vial}$ & Injection \\
\hline 13 & Infectious disease & Chloramphenicol & $1 \mathrm{~g} / \mathrm{vial}$ & Injection \\
\hline 14 & Infectious disease & Cotrimoxazole (Trimethoprin + Sulfamethoxazole) ${ }^{*}$ & $8+40 \mathrm{mg} / \mathrm{ml}$ & Suspension \\
\hline 15 & Infectious disease & Gentamicin* & $10 \mathrm{mg} / \mathrm{ml}$ & Injection \\
\hline 16 & Infectious disease & Procaine Penicillin G* & $4 \mathrm{M}$ units/vial & Injection \\
\hline 17 & Malaria & Primaquine & $15 \mathrm{mg}$ & Cap/tab \\
\hline 18 & Pain/inflammation & Ibuprofen & $200 \mathrm{mg}$ & Cap/tab \\
\hline 19 & Pain/inflammation & Paracetamol* & $25 \mathrm{mg} / \mathrm{ml}$ & syrup/susp \\
\hline 20 & Pain & Morphine Sulfate & $10 \mathrm{mg} / \mathrm{ml}$ & Injection \\
\hline 21 & Xerophthalmia & Vitamin A & 50,000 units & Cap/tab \\
\hline 22 & Tuberculosis & Isoniazid & $100 \mathrm{mg}$ & Cap/tab \\
\hline 23 & Anemia & Ferrous Salt* & $125 \mathrm{mg} / 5 \mathrm{ml}$ & Suspension \\
\hline 24 & Seizure Disorder & Diazepam & $5 \mathrm{mg} / \mathrm{ml}$ & Injection \\
\hline 25 & Seizure Disorder & Carbamazepine & $100 \mathrm{mg} / 5 \mathrm{ml}$ & Suspension \\
\hline 26 & Seizure Disorder & Phenobarbital & $3 \mathrm{mg} / \mathrm{ml}$ & Oral liquid \\
\hline 27 & Seizure Disorder & Phenytoin & 25 or $30 \mathrm{mg} / 5 \mathrm{ml}$ & Suspension \\
\hline 28 & Device - asthma & Spacer & $\mathrm{n} / \mathrm{a}$ & $\mathrm{n} / \mathrm{a}$ \\
\hline
\end{tabular}

* $=$ medicine listed on Lista Basica.

information on medicine availability and price using a standard data collection form specific to the medicines being surveyed in Guatemala. The data collectors entered survey data into the pre-programmed MS Excel Workbook provided as part of the WHO/HAI methodology. Data collection was verified in roughly $10 \%$ of pharmacies, data were double-entered and the data checker function on the spreadsheet was used to identify data entry errors.

Three medicines were excluded from the analysis leaving a total of 24 medicines and 1 device for analysis. Phenytoin and phenobarbital suspensions were excluded as the incorrect strengths of the medications were printed on the data collection sheets. Beclomethasone inhaler was omitted from the analysis because although it was included on the core list of children's medicines for the survey, it was deleted from the EMLc in 2009 [17]. Of note, it was not found in any of the pharmacies surveyed in Guatemala. We calculated the availability of individual medicines as the percentage of sampled medicine outlets where the medicine was found. Data are reported in aggregate and by private vs. public sector pharmacies. We also report mean (average) availability for the list of medicines surveyed.

\section{Cross-country comparisons}

To facilitate cross-country comparisons, medicine prices obtained during the survey were expressed as ratios relative to a standard set of international reference prices:

$$
\text { Medicine } \cdot \text { Price } \cdot \text { Ratio } \cdot(M P R) \cdot=\cdot \frac{\text { median } \cdot \text { local } \cdot \text { unit } \cdot \text { price }}{\text { international } \cdot \text { reference } \cdot \text { unit } \cdot \text { price }}
$$

Medicine price ratios were calculated only for medicines with price data from at least 4 medicine outlets. The exchange rate used to calculate MPRs was 1 US 
$\$=8.1513$ Quetzales; this was the commercial "buy" rate taken from OANDA.com on the first day of data collection [18].

We used the 2009 Management Sciences for Health $(\mathrm{MSH})$ reference prices, taken from the International Drug Price Indicator Guide [19]. These reference prices are the medians of recent procurement prices offered for generic products by for-profit and not-for-profit suppliers to international not-for-profit agencies.

\section{Affordability}

We assessed the affordability of treating eight of common conditions causing high rates of morbidity and mortality of children in Guatemala by comparing the total cost of medicines prescribed at a standard dose to the daily wage of the lowest paid unskilled government worker at 56 quetzales ( $\$ 6.87$ USD per day) at the time of the survey. For acute conditions, treatment duration was defined as a full course of therapy, while for chronic diseases, the affordability of a 30-days' supply of medicines was determined. Though it is difficult to assess true affordability, treatments costing one days' wage or less were considered affordable [7].

This study was approved by the University of California, San Francisco Committee on Human Research, approval number H2758-35862.

\section{Results}

\section{Availability of medicines on the day of data collection}

As shown in Table 2, the availability of individual medicines varied by type of medicine and sector. Average availability of all surveyed medications was very low. Public tertiary hospitals had the highest availability of medicines found with an average of 46\% (range 28-56\%) of medicines found in each outlet. Average availability in the private sector was 35\% (range 10-52\%) for lowest priced medicines. Average availability for a second, higher priced medicine when a lower price medicine was found, was $12 \%$ in the private sector.

The PROAM sector had the lowest availability at $25 \%$ (range 5-43\%). In the PROAM sector, generics were the predominant product type available, with $98 \%(142 / 145)$ of medicines found as generics. Although we expected that only medicines found on the Lista Basica would be stocked, some of these medicines had low availability including ferrous salt suspension (24\%), gentamicin injection (33\%) and procaine penicillin G (29\%). When we limited the analysis to the 11 survey medicines found only on the Lista Basica (Table 1), availability increased to $57 \%$ (range $9-82 \%$ ) in the PROAM sector. The availabilities of individual medicines in the PROAM, public tertiary hospitals and private sectors are shown in Table 3.

\section{PROAM and private sector patient prices}

As shown in Table 4, lowest price medicines are generally sold at 1.73 times their international reference price in the PROAM sector. Half of the lowest priced generic medicines were priced at $1.24\left(25^{\text {th }}\right.$ percentile $)$ to $2.32\left(75^{\text {th }}\right.$ percentile) times their international reference price, showing moderate variation in medicine price ratios across individual generic medicines in the PROAM sector.

In contrast, substantial variation exists in median price ratios in the private sector. We compared prices between lowest and highest priced products for six medicines for which more than one price option was found. In the private sector, higher price medications cost twice as much, on average, as their lowest priced equivalents. Higher priced medicines were 22.67 times more expensive than their international reference price. The cost of half of these medicines ranged from 11.21 ( $25^{\text {th }}$ percentile) to 35.51 ( $75^{\text {th }}$ percentile) times their international reference price. Lowest price medicines were 10.46 times their international reference price with half of these medicines priced at $5.57\left(25^{\text {th }}\right.$ percentile) to $16.99\left(75^{\text {th }}\right.$ percentile $)$ times their international reference.

\section{Comparison of patient prices in the PROAM and private sectors}

Median price ratios were substantially higher in the private sector compared to the PROAM sector. Nine medicines that were found in both PROAM and private sectors had data available for price comparisons. As the median MPR was 1.61 and 10.32 for PROAM and private sectors, respectively, final patient prices were 6.41 times higher in the private sector than in the PROAM sector.

\section{Affordability of standard treatment regimens}

As shown in Table 5, lowest price medicines in the private sector were less affordable than in the PROAM sector for most conditions, with standard treatment costing a days' wage or more. Medicines costing over a days' wage include ceftriaxone injection for susceptible infection costing 15 days wages and carbamazepine suspension for seizure disorders costing 6.6 days wages.

\section{Discussion}

The availability of essential children's medicines is low in both the public and private sectors in Guatemala. Availability is lowest in the public sector, but there is inconsistent pricing and poor affordability of medicines in the private sector. Furthermore, formulations of medications that are preferable for use in children were often hard to find. Of the 30 medicine formulations in the survey protocol, seven were not assessed because they are not registered in Guatemala [6]. These consisted of dispersible (3) and chewable (2) tablets, oral liquid (1) and intrarectal solution (1); all formulations preferred for use 
Table 2 Availability of lowest price medications by sector

\begin{tabular}{|c|c|c|c|}
\hline & Public hospital & Public PROAM & Private \\
\hline Medicines not found in any & Amoxicillin pediatric drops & Amoxicillin pediatric drops & Chloramphenicol injection \\
\hline \multirow[t]{16}{*}{ outlets * } & Amoxicillin suspension & Amoxicillin suspension & Ferrous Salt suspension \\
\hline & $125 \mathrm{mg}$ & $125 \mathrm{mg}$ & Gentamicin injection \\
\hline & Amoxicillin-Clav & Amoxicillin-Clav & Isoniazid tablets \\
\hline & suspension $125 \mathrm{mg}$ & suspension $125 \mathrm{mg}$ & Morphine Sulfate \\
\hline & Amoxicillin-Clav & Carbamazepine & injection \\
\hline & suspension 250mg & suspension & Primaquine tablets \\
\hline & Carbamazepine & Chloramphenicol & Zinc dispersible tablets \\
\hline & suspension & Injection & \\
\hline & Ibuprofen tablets & Diazepam Injection & \\
\hline & Salbutamol (Albuterol) & Ibuprofen tablets & \\
\hline & inhaler & Isoniazid tablets & \\
\hline & Spacer & Morphine Sulfate & \\
\hline & & injection & \\
\hline & & Primaquine tablets & \\
\hline & & Spacer & \\
\hline & & Zinc dispersible tablets & \\
\hline \multirow[t]{9}{*}{ Medicines found in less than $25 \%$ of outlets } & Primaquine tablets & Ferrous salt suspension & Amoxicillin pediatric \\
\hline & Vitamin A tablets & Oral Rehydration & drops \\
\hline & Zinc dispersible tablets & Solution & Amoxicillin-Clav \\
\hline & & Vitamin A tablets & suspension 250mg \\
\hline & & & Carbamazepine \\
\hline & & & suspension \\
\hline & & & Diazepam injection \\
\hline & & & Spacer \\
\hline & & & Vitamin A \\
\hline \multirow[t]{7}{*}{ Medicines found in 25 to $49.9 \%$ of outlets } & & Ceftriaxone Injection & Amoxicillin suspension \\
\hline & & Gentamicin injection & $125 \mathrm{mg}$ \\
\hline & & Procaine Penicillin G & Amoxicillin suspension \\
\hline & & Salbutamol (Albuterol) & $250 \mathrm{mg}$ \\
\hline & & Inhaler & Amoxicillin-Clav \\
\hline & & & suspension $125 \mathrm{mg}$ \\
\hline & & & Procaine Penicillin G \\
\hline \multirow[t]{7}{*}{ Medicines found in 50 to $74.9 \%$ of outlets } & Amoxicillin suspension & Amoxicillin suspension & Benzathine Penicillin G \\
\hline & $250 \mathrm{mg}$ & $250 \mathrm{mg}$ & injection \\
\hline & Chloramphenicol & Amoxicillin-Clav & Ibuprofen tablets \\
\hline & Injection & 250mg suspension & Oral Rehydration \\
\hline & Isoniazid tablets & Cotrimoxazole & Solution, powder \\
\hline & Oral Rehydration Solution & (Trimethoprim + Sulfamethoxazole & Salbutamol (Albuterol) Inhaler \\
\hline & & Paracetamol (Acetaminophen) & \\
\hline \multirow[t]{3}{*}{ Medicines found in $75 \%$ or more of outlets } & Benzathine Penicillin G & Benzathine Penicillin G & Ceftriaxone injection \\
\hline & injection & injection & Cotrimoxazole \\
\hline & Ceftriaxone Injection & Oral Rehydration & (Trimethoprim + \\
\hline
\end{tabular}


Table 2 Availability of lowest price medications by sector (Continued)

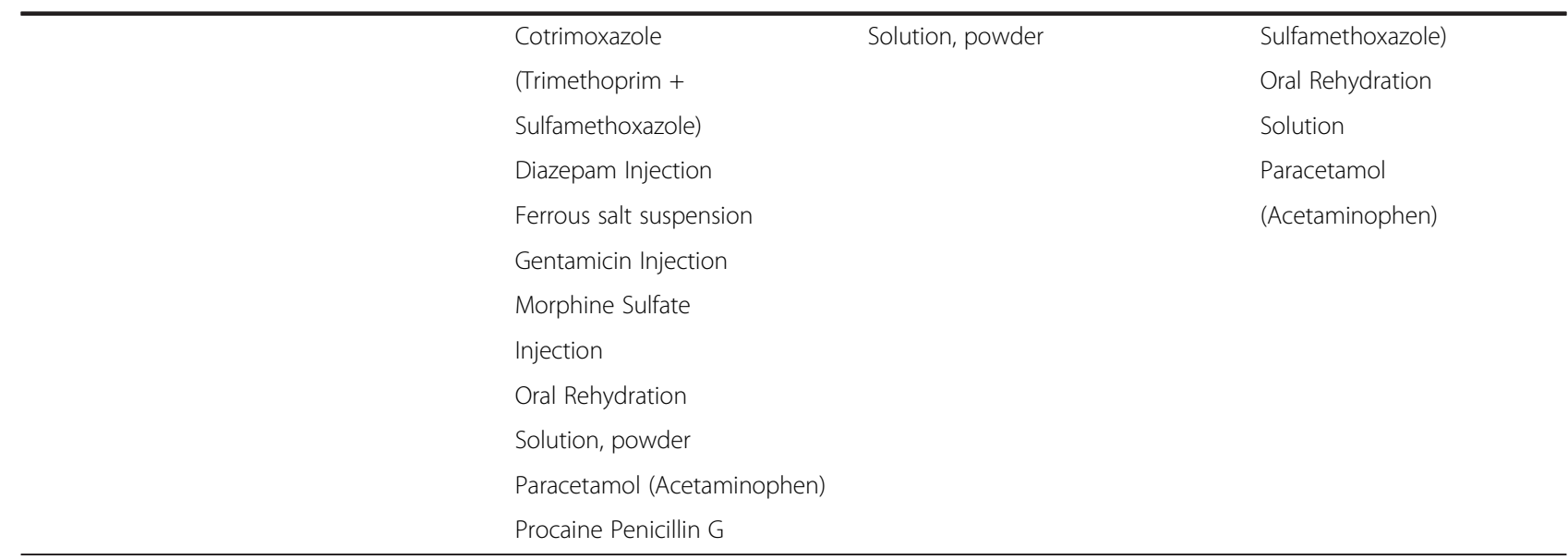

*in the PROAM sector, the Lista Basica determines the medications stocked in the pharmacy. Medications not found in any PROAM outlets were medications not on the Lista Basica.

Table 3 Availability of individual medicines in the public, PROAM and private sector

\begin{tabular}{|c|c|c|c|c|}
\hline \multirow[b]{3}{*}{ Medicine name } & \multicolumn{4}{|c|}{ Percentage of outlets where medicine was found } \\
\hline & \multirow{2}{*}{$\begin{array}{c}\begin{array}{c}\text { Public sector } \\
(n=4 \text { outlets })\end{array} \\
\text { Lowest price medication }\end{array}$} & \multirow{2}{*}{$\begin{array}{c}\text { PROAM sector } \\
(n=21 \text { outlets })\end{array}$} & \multicolumn{2}{|c|}{$\begin{array}{l}\text { Private sector } \\
(\mathrm{n}=29 \text { outlets) }\end{array}$} \\
\hline & & & $\begin{array}{l}\text { Highest price } \\
\text { medication }\end{array}$ & $\begin{array}{c}\text { Lowest price } \\
\text { medication }\end{array}$ \\
\hline Amoxicillin Pediatric Drops & $0.0 \%$ & $0.0 \%$ & $6.9 \%$ & $20.7 \%$ \\
\hline Amoxicillin Suspension $125 \mathrm{mg}$ & $0.0 \%$ & $0.0 \%$ & $6.9 \%$ & $34.5 \%$ \\
\hline Amoxicillin Suspension 250mg & $50 \%$ & $61.9 \%$ & $6.9 \%$ & $48.3 \%$ \\
\hline Amoxicillin-Clav Suspension 125mg & $0.0 \%$ & $0.0 \%$ & $10.3 \%$ & $41.4 \%$ \\
\hline Amoxicillin-Clav Suspension 250mg & $0.0 \%$ & $57.1 \%$ & $3.4 \%$ & $13.8 \%$ \\
\hline Benzathine Penicillin G Injection & $75 \%$ & $90.5 \%$ & $20.7 \%$ & $69.0 \%$ \\
\hline Carbamazepine Suspension & $0.0 \%$ & $0.0 \%$ & $3.4 \%$ & $20.7 \%$ \\
\hline Ceftriaxone Injection & $100 \%$ & $47.6 \%$ & $27.6 \%$ & $82.8 \%$ \\
\hline Chloramphenicol Injection & $50 \%$ & $0.0 \%$ & $0.0 \%$ & $0.0 \%$ \\
\hline $\begin{array}{l}\text { Cotrimoxazole } \\
\text { (Trimethoprim + Sulfamethoxazole) }\end{array}$ & $100 \%$ & $57.1 \%$ & $51.7 \%$ & $89.7 \%$ \\
\hline Diazepam Injection & $75 \%$ & $0.0 \%$ & $0.0 \%$ & $13.8 \%$ \\
\hline Ferrous salt suspension & $75 \%$ & $23.8 \%$ & $0.0 \%$ & $0.0 \%$ \\
\hline Gentamicin Injection & $100 \%$ & $33.3 \%$ & $0.0 \%$ & $0.0 \%$ \\
\hline Ibuprofen & $0.0 \%$ & $0.0 \%$ & $13.8 \%$ & $58.6 \%$ \\
\hline Isoniazid & $50 \%$ & $0.0 \%$ & $0.0 \%$ & $0.0 \%$ \\
\hline Morphine Sulfate Injection & $75 \%$ & $0.0 \%$ & $0.0 \%$ & $0.0 \%$ \\
\hline Oral Rehydration Solution & $50 \%$ & $9.5 \%$ & $69.0 \%$ & $96.6 \%$ \\
\hline Oral Rehydration Solution, powder & $100 \%$ & $81.0 \%$ & $0.0 \%$ & $72.4 \%$ \\
\hline Paracetamol (Acetaminophen) & $75 \%$ & $71.4 \%$ & $41.4 \%$ & $82.8 \%$ \\
\hline Primaquine & $25 \%$ & $0.0 \%$ & $0.0 \%$ & $0.0 \%$ \\
\hline Procaine Penicillin G & $100 \%$ & $28.6 \%$ & $3.4 \%$ & $27.6 \%$ \\
\hline Salbutamol (Albuterol) Inhaler & $0.0 \%$ & $42.9 \%$ & $34.5 \%$ & $62.1 \%$ \\
\hline Spacer & $0.0 \%$ & $0.0 \%$ & $3.4 \%$ & $13.8 \%$ \\
\hline Vitamin A & $25 \%$ & $9.5 \%$ & $0.0 \%$ & $13.8 \%$ \\
\hline Zinc & $25 \%$ & $0.0 \%$ & $0.0 \%$ & $0.0 \%$ \\
\hline
\end{tabular}


Table 4 Median price ratios of lowest priced medicines, private and PROAM sector patient prices

\begin{tabular}{|c|c|c|}
\hline \multirow[t]{2}{*}{ Medicine name } & \multicolumn{2}{|c|}{$\begin{array}{l}\text { Lowest price medication } \\
\text { MPR }\left(25^{\text {th }}-75^{\text {th }} \text { percentile }\right)\end{array}$} \\
\hline & Private sector & PROAM sector \\
\hline Amoxicillin Suspension $125 \mathrm{mg}$ & $18.86(14.65-19.54)$ & $\mathrm{n} / \mathrm{a}$ \\
\hline Amoxicillin Suspension 250mg & $13.88(9.60-19.55)$ & $1.85(1.56-2.04)$ \\
\hline Amoxicillin-Clav Suspension 125mg & $6.13(4.50-6.13)$ & $\mathrm{n} / \mathrm{a}$ \\
\hline Amoxicillin-Clav Suspension 250mg & $2.53(2.16-2.76)$ & $0.60(0.53-0.70)$ \\
\hline Benzathine Penicillin G Injection & $35.54(19.33-41.78)$ & $4.51(3.16-5.86)$ \\
\hline Carbamazepine Suspension & $3.04(2.70-3.37)$ & $\mathrm{n} / \mathrm{a}$ \\
\hline Ceftriaxone Injection & $13.20(7.65-18.70)$ & $1.61(1.10-1.65)$ \\
\hline Cotrimoxazole suspension & $10.32(6.42-16.48)$ & $1.37(1.20-1.82)$ \\
\hline Diazepam Injection & $19.70(16.08-26.26)$ & $\mathrm{n} / \mathrm{a}$ \\
\hline Gentamicin Injection & $\mathrm{n} / \mathrm{a}$ & $2.77(2.08-3.46)$ \\
\hline Ibuprofen & $31.54(30.07-36.08)$ & $\mathrm{n} / \mathrm{a}$ \\
\hline Oral Rehydration Solution, powder & $5.01(4.38-7.51)$ & $1.88(1.25-2.75)$ \\
\hline Paracetamol (Acetaminophen) & $6.26(4.72-7.65)$ & $1.05(0.89-1.70)$ \\
\hline Procaine Penicillin G & $10.46(9.15-12.30)$ & $2.46(2.04-2.65)$ \\
\hline Salbutamol (Albuterol) Inhaler & $4.94(3.49-5.56)$ & $1.20(0.94-1.21)$ \\
\hline Vitamin A & $15.13(12.45-15.58)$ & n/a \\
\hline
\end{tabular}

* Medicine price ratios (MPRs) were calculated only for medicines with price data from at least 4 medicine outlets.

in children. It is unclear if the lack of registered medicines for children is related to low prescriber demand similar to the case with magnesium sulfate in Zambia, or exclusion from the contrato abierto, the central government purchasing mechanism, due to high purchasing prices [20]. Guatemala is subject to rules and regulations under Trade Related Aspects of Intellectual Property Rights (TRIPS). Essential medicines that have been reformulated to be better suited for children may be under patent and therefore more expensive in Guatemala for up to 5 to 15 years after becoming generic in the United States [11]. Another factor that may be responsible for a dearth of registered child friendly formulations may be difficultly obtaining the product if it is not manufactured in the country or nearby. As suggested in previous literature, studies of local prescribing practices and government purchasing are required to fully answer these questions [5]. Development of a national essential medicines list that includes children's medicines could increase demand from providers and guide purchasing decisions [21].

Among the surveyed medicines, originator brands were almost never available in the PROAM sector as the government contracts with generic pharmaceutical companies to procure less expensive medications. In addition, the availability of generic medicines in the PROAM sector was exceptionally low with only about one quarter of index medicines stocked in each outlet. These findings are similar to a recent study on the accessibility of children's medicines in 14 African countries, where essential children's medicines were available at central medicine stores 15 to $75 \%$ of time with only 3 medicine outlets containing over $50 \%$ of medicines [5]. Our findings are also consistent with a number of pricing and availability surveys that have been conducted for adult medicines for both acute and chronic diseases [22-25]. These studies show that availability of essential medicines is lower in the public than the private sector, varies by country, and that medicines for chronic conditions are less available than those for acute conditions.

Seven medications were not found at all in the private sector. One medication, chloramphenicol injection, was not stocked due to concerns about its toxicity. One would expect the remainder of these medicines to be found at the hospital level and therefore, not stocked in outpatient outlets. However, as the availability in hospitals is low, friends or family of hospitalized patients often go to alternate locations such as private retail pharmacies to purchase medications. Even the poorest patients in Guatemala seek medicines from the private sector [26].

Diarrheal disease is one of the major causes of mortality in children under five in Guatemala [8]. Although oral rehydration powders for reconstitution and premixed solutions for treatment of diarrhea were available in the PROAM and private sectors, oral zinc was unavailable in these sectors and the mean availability was only $25 \%$ in the hospital setting. Zinc is included on the EMLc due to its benefit in treating children with diarrhea [27].

Antibiotics for treating pneumonia and other respiratory infections in children should be available for use as empiric treatment, to decrease a major cause of morbidity in children [8]. While ceftriaxone was found quite frequently in the private and public sectors, it was only available in about half of the PROAM outlets. Amoxicillin and amoxicillin-clavulanic acid were available most frequently in $250 \mathrm{mg} / 5 \mathrm{ml}$ concentration. When child appropriate concentrations are not available, pharmacy employees must calculate the dose. This could lead to adverse drug events as pharmacy employees in low income countries may need additional training [28].

In the PROAM sector, affordability of lowest price medicines was reasonable compared to the private sector where many of lowest priced treatments cost more than the daily wage of a lowest paid government employee. In the private sector, the most unaffordable treatments were for seizure disorder with carbamazepine (6.6 days wages) and infections with ceftriaxone (15 days wages). Carbamazepine is an ongoing treatment for a chronic condition, making it even less affordable. Given that $24 \%$ of the population in Guatemala is living below the international poverty line of less than $\$ 2 /$ day, treatments 
Table 5 Affordability: Number of days' wages of worker making lowest paid government wages needed to purchase standard treatments

\begin{tabular}{|c|c|c|c|c|}
\hline \multicolumn{3}{|c|}{ Disease condition and 'standard' treatment } & \multicolumn{2}{|c|}{ Day's wages to pay for treatment } \\
\hline Condition & $\begin{array}{l}\text { Drug name, strength, } \\
\text { dosage form }\end{array}$ & Treatment schedule & $\begin{array}{c}\text { Lowest price } \\
\text { medication - } \\
\text { Private Sector }\end{array}$ & $\begin{array}{l}\text { Lowest price } \\
\text { medication - } \\
\text { PROAM secto }\end{array}$ \\
\hline $\begin{array}{l}\text { Respiratory Tract } \\
\text { Infections, UTIs }\end{array}$ & $\begin{array}{l}\text { Amoxicillin Suspension } 125 \\
\mathrm{mg} / 5 \mathrm{~mL}\end{array}$ & $\begin{array}{l}\text { Child up to } 10 \text { years: } 125 \mathrm{mg} \\
(=5 \mathrm{ml}) \times 3 \times 7 \text { days }=105 \mathrm{ml}\end{array}$ & 1.3 & $\mathrm{n} / \mathrm{a}$ \\
\hline $\begin{array}{l}\text { Respiratory Tract } \\
\text { Infections, UTIs }\end{array}$ & $\begin{array}{l}\text { Amoxicillin Suspension } 250 \\
\mathrm{mg} / 5 \mathrm{~mL}\end{array}$ & $\begin{array}{l}\text { Child over } 10 \text { years: } 250 \mathrm{mg} \\
(=5 \mathrm{ml}) \times 3 \times 7 \text { days }=105 \mathrm{ml}\end{array}$ & 1.3 & 0.2 \\
\hline $\begin{array}{l}\text { Respiratory Tract } \\
\text { Infections, Otitis Media }\end{array}$ & $\begin{array}{l}\text { Amoxicillin-Clavulanic Acid } \\
\text { Suspension } 125-31.25 \mathrm{mg} / 5 \mathrm{ml}\end{array}$ & $\begin{array}{l}\text { Child } 1-6 \text { years: } 125 \mathrm{mg}(=5 \mathrm{ml}) \times \\
3 \times 7 \text { days }=105 \mathrm{ml}\end{array}$ & 2.2 & $\mathrm{n} / \mathrm{a}$ \\
\hline $\begin{array}{l}\text { Respiratory Tract } \\
\text { Infections, Otitis Media }\end{array}$ & $\begin{array}{l}\text { Amoxicillin-Clavulanic Acid } \\
\text { Suspension } 250-62.5 \mathrm{mg} / 5 \mathrm{ml}\end{array}$ & $\begin{array}{l}\text { Child over } 10 \text { years: } 250 \mathrm{mg} \\
(=5 \mathrm{ml}) \times 3 \times 7 \text { days }=105 \mathrm{ml}\end{array}$ & 2.6 & 0.6 \\
\hline Seizure Disorder & $\begin{array}{l}\text { Carbamazepine Suspension } \\
100 \mathrm{mg} / 5 \mathrm{ml}\end{array}$ & $\begin{array}{l}\text { Maintenance treatment: } 5 \mathrm{mg} / \mathrm{kg} \times \\
18 \mathrm{~kg}^{*} \times 3 \times 30 \text { days }=8100 \mathrm{mg} \text { or } \\
405 \mathrm{~mL} \text { for } 1 \text { month. }\end{array}$ & 6.6 & $\mathrm{n} / \mathrm{a}$ \\
\hline $\begin{array}{l}\text { Infections due to } \\
\text { Susceptible Organisms }\end{array}$ & Ceftriaxone 500 mg vial & $\begin{array}{l}\text { Child under } 50 \text { kg: Maximum } 1 \\
\text { gram daily } \times 7 \text { days. }\end{array}$ & 15 & 1.8 \\
\hline $\begin{array}{l}\text { Infections due to } \\
\text { Susceptible Organisms }\end{array}$ & Cotrimoxazole & $\begin{array}{l}18 \mathrm{~kg} \times 4 \mathrm{mg} / \mathrm{kg}=72 \mathrm{mg} \mathrm{TMP} \times 2 \\
\times 7 \text { days }=1008 \mathrm{mg} .126 \mathrm{ml} \text { total } \\
\text { for } 7 \text { days. }\end{array}$ & 0.8 & 0.1 \\
\hline Dehydration & $\begin{array}{l}\text { Oral Rehydration Solution, } \\
\text { powder to make } 500 \mathrm{~mL}\end{array}$ & $\begin{array}{l}\text { Moderate Dehydration: } 75 \mathrm{~mL} / \mathrm{kg} \\
\times 18 \mathrm{~kg}=1350\end{array}$ & 0.1 & $\mathrm{n} / \mathrm{a}$ \\
\hline Pneumonia & Procaine Penicillin G & $\begin{array}{l}50 \mathrm{mg} / \mathrm{kg} \times 18 \mathrm{~kg}=900 \mathrm{mg} \times 10 \\
\text { days }=9000 \mathrm{mg}\end{array}$ & 1.7 & 0.4 \\
\hline Pain/inflammation & $\begin{array}{l}\text { Paracetamol 24mg/ml } \\
\text { suspension }\end{array}$ & $\begin{array}{l}5 \text { year old child: } 15 \mathrm{mg} / \mathrm{kg} \times 18 \mathrm{~kg} \\
\times 4 \times 3=3240 \mathrm{mg}(=130 \mathrm{~mL})\end{array}$ & 0.5 & 0.1 \\
\hline Asthma & $\begin{array}{l}\text { Salbutamol } 100 \mathrm{mcg} / \text { dose } \\
\text { inhaler }\end{array}$ & 1 inhaler of 200 doses & 1.3 & 0.3 \\
\hline Xerophthalmia & Vitamin A 50,000 units & $\begin{array}{l}\text { Child } 1-12 \text { years: } 200,000 \text { units } x \\
3 \text { doses }\end{array}$ & 0.4 & $\mathrm{n} / \mathrm{a}$ \\
\hline
\end{tabular}

*Weight of average 5 year old child in Guatemala $=18 \mathrm{~kg}[31,32]$.

which appear affordable may still be too costly [29]. In addition, treatment costs refer to medicines only and do not include the additional costs of consultation and diagnostic tests. Finally, families who need medications for more than one child may be confronted with insurmountable drug costs. These findings are consistent with other studies of affordability of adult medicines showing that chronic medicines, in particular, are unaffordable for many populations $[22,23,25,30]$.

A major strength of this study is the use of a previously validated methodology which allows for the measurement of medicine prices and availability in a reliable and standardized way [16]. Additional strengths include training and utilization of multiple check points to ensure quality data collection, data entry and interpretation.

Limitations of the WHO/HAI methodology are consistent with past surveys. Therapeutic alternatives or alternate dosage forms were not assessed. The availability data refers to the day of data collection at each particular facility in subsectors of the country and may not reflect average monthly or yearly availability of medicines at individual facilities or throughout the entire country. Also, the standard for determining the median price ratio is the median of supplier prices. However, if supplier prices are not available, buyer prices are substituted to determine the median international reference price for the different medications. This can lead to artificially high or low reference price that isn't necessarily indicative of true median price paid internationally [25]. NGOs, private dispensing doctors and unregistered dispensaries were not surveyed and their importance as a source of medicines for those with low socioeconomic status is unknown. Further investigation is warranted into the amount that these sources contribute to accessibility to medications in Guatemala.

\section{Conclusion}

The findings of this study can be used to structure policies to improve the accessibility of children's medicines in Guatemala and help the country meet MDG4 in 2015. Monitoring the availability and pricing of children's essential medicines in Guatemala and other countries is crucial 
for improving transparency about global prices. Updated lists of all registered pharmacies are needed to facilitate these analyses. Inclusion of the WHO's Essential Medicines List for children into national formularies and purchasing lists such as the PROAM and contrato abierto could improve the availability of essential children's medicines. Data should be collected on prescribing practices of local pediatricians to detect deficiencies, if any, in rational prescribing and develop educational programs to improve prescribing of medicines from the EMLc [5]. The coordination of the WHO EMLc with national clinical practice guidelines could promote physician use of essential medicines. Further analysis of the procurement, supply and distribution of specific medicines is needed to determine reasons for lack of availability [20].

\section{Competing interest}

The authors declare that they have no competing interests.

\section{Author's contributions}

$A A, B R$, ARE and LB conceived of the study, and participated in its design and coordination and helped to draft the manuscript. All authors read and approved the final manuscript.

\section{Author's information}

AA is a PharmD and a Pharmacy Practice Resident at University of San Francisco, California Medical Center. BR is a PharmD and a Health Sciences Assistant Clinical Professor at University of San Francisco, California and a Professor in the Departamento de Química-Farmacéutica at the Universidad del Valle de Guatemala. ARE is an MPH and a consultant at Cedar Associates. $\mathrm{LB}$ is a PhD and Professor of Clinical Pharmacy and Health Policy.

\section{Acknowledgments}

This project was supported by NIH/NCRR/OD UCSF-CTSI Grant Number TL1 RR024129. Its contents are solely the responsibility of the authors and do not necessarily represent the official views of the $\mathrm{NIH}$.

Special thanks go to Licenciada Ana Margarita Contreras Sandoval, whose knowledge and hard work were priceless. We also thank Licenciado Elfegio Rolando Lopez, Steven Kayser, Nancy Hessol, Claire Lee, Ellen Shafer, Alexandra Cameron, Daniela Fernandez, Roberto Contreras Sandoval, Diego Rodriguez, Andres Hernandez, Carlos Alvarez and Ana Irene Perez.

\section{Author details}

${ }^{1}$ Department of Clinical Pharmacy, University of California, San Francisco, CA 94143-0622, USA. 'La Universidad del Valle de Guatemala, Vista Hermosa III, Guatemala City, Guatemala 01015. ${ }^{3}$ Cedar Associates, Menlo Park, CA 94025, USA. ${ }^{4}$ Department of Clinical Pharmacy, Institute for Health Policy Studies, University of California, San Francisco, CA 94118, USA.

Received: 6 March 2012 Accepted: 13 June 2012

Published: 2 July 2012

\section{References}

1. World Health Organization: Communicable Disease Cluster: Removing obstacles to healthy development: report on infectious diseases. http://www. who.int/infectious-disease-report/pages/textonly.htm

2. United Nations Childrens' Fund: The state of the world's children 2008. New York: UNICEF; 2007.

3. The United Nations: The millenium development goals report 2010. New York: United Nations; 2010.

4. Rajaratnam JK, Marcus JR, Flaxman AD, Wang H, Levin-Rector A, Dwyer L, Costa M, Lopez AD, Murray CJ: Neonatal, postneonatal, childhood, and under-5 mortality for 187 countries, 1970-2010: a systematic analysis of progress towards Millennium Development Goal 4. Lancet 2010, 375(9730):1988-2008.
5. Robertson J, Forte G, Trapsida JM, Hill S: What essential medicines for children are on the shelf? Bull World Health Organ 2009, 87(3):231-237.

6. Overview of methods for medicines availability and pricing surveys: Better Medicines for Children Project. http://www.who.int/childmedicines/progress/ ChildMeds_pricing_surveys.pdf

7. Health Action International; World Health Organization: Meassuring medicine prices, availability, affordability and price components. http://www.haiweb. org/medicineprices/manual/documents.html

8. Pan American Health Organization: Health in the Americas: Guatemala. http://www.paho.org/hia/archivosvol2/paisesing/Guatemala\%20English.pdf

9. Congreso de la República de Guatemala: Ley de accesibilidad a los medicamentos. 1998:69-98.

10. Congreso de la República de Guatemala: Ley de contrataciones del estado. 1992:57-92.

11. Shaffer ER, Brenner JE: A trade agreement's impact on access to generic drugs. Health Aff (Millwood) 2009, 28(5):w957-w968

12. Ventas sociales y farmacias privadas: Ministerio de Salud. http://www.mspas. gob.gt/

13. Jefatura del departamento de regulación y control de productos farmacéuticos y afines. 2001. http://www.medicamentos.com.gt/index.php/legislacionvigente/normas-tecnicas?start $=40$

14. Jefatura del departamento de regulación y control de productos farmacéuticos y afines. 2002. http://www.medicamentos.com.gt/index.php/legislacionvigente/normas-tecnicas?start $=40$

15. Jefatura del departamento de regulación y control de productos farmacéuticos y afines. 2003. http://www.medicamentos.com.gt/index.php/legislacionvigente/normas-tecnicas?start $=40$

16. Madden JM, Meza E, Ewen M, Laing RO, Stephens P, Ross-Degnan D: Measuring medicine prices in Peru: validation of key aspects of WHO/ HAl survey methodology. Rev Panam Salud Publica 2010, 27(4):291-299.

17. World Health Organization: WHO model list of essential medicines for children: 2nd ed. Geneva, Switzerland: WHO; 2009.

18. OANDA: http://www.oanda.com/currency/converter/

19. Management Sciences for Health: International drug price indicator guide. http://erc msh.org/mainpage.cfm?file=1.0.htm\&\&module=DMP\&language=English

20. Ridge AL, Bero LA, Hill SR: Identifying barriers to the availability and use of Magnesium Sulphate Injection in resource poor countries: a case study in Zambia. BMC Health Serv Res 2010, 10:340.

21. Priority Medicines for Maternal and Child Health: A Global Survey of National Essential Medicines Lists. [http://www.plosone.org/article/info\%3Adoi\% 2F10.1371\%2Fjournal.pone.0038055]

22. Mendis S, Fukino K, Cameron A, Laing R, Filipe A Jr, Khatib O, Leowski J, Ewen M: The availability and affordability of selected essential medicines for chronic diseases in six low- and middle-income countries. Bull World Health Organ 2007, 85(4):279-288.

23. van Mourik MS, Cameron A, Ewen M, Laing RO: Availability, price and affordability of cardiovascular medicines: a comparison across 36 countries using WHO/HAI data. BMC Cardiovasc Disord 2010, 10:25.

24. Cameron A, Roubos I, Ewen M, Mantel-Teeuwisse AK, Leufkens HG, Laing RO: Differences in the availability of medicines for chronic and acute conditions in the public and private sectors of developing countries. Bull World Health Organ 2011, 89(6):412-421.

25. Cameron A, Ewen M, Ross-Degnan D, Ball D, Laing R: Medicine prices, availability, and affordability in 36 developing and middle-income countries: a secondary analysis. Lancet 2009, 373(9659):240-249.

26. Gwatkin DR, Rutstein S, Johnson K, Suliman E, Wagstaff A, Amouzou A: Socio-economic differences in health, nutrition, and population within developing countries: an overview. Niger J Clin Pract 2007, 10(4):272-282.

27. Strand TA, Chandyo RK, Bahl R, Sharma PR, Adhikari RK, Bhandari N, Ulvik RJ, Molbak K, Bhan MK, Sommerfelt H: Effectiveness and efficacy of zinc for the treatment of acute diarrhea in young children. Pediatrics 2002, 109(5):898-903.

28. Goel P, Ross-Degnan D, Berman P, Soumerai S: Retail pharmacies in developing countries: a behavior and intervention framework. Soc Sci Med 1996, 42(8):1155-1161.

29. Worldbank: Data by country. http://data.worldbank.org/country/guatemala.

30. Niens LM, Cameron A, Van de Poel E, Ewen M, Brouwer WB, Laing R: Quantifying the impoverishing effects of purchasing medicines: a crosscountry comparison of the affordability of medicines in the developing world. PLoS Med 2010, 7(8):e1000333. 
31. World Health Organization. (2010). WHO model formulary for children. Geneva, Switzerland: World Health Organization. Retrieved 26 March 2011, from http://www.who.int/selection_medicines/list/WMFc_2010.pdf

32. World Health Organization. (2011). Child growth standards. Retrieved 26 March, 2011, from http://www.who.int/childgrowth/standards/ weight_for_age/en/index.html

doi:10.1186/1744-8603-8-22

Cite this article as: Anson et al: Availability, prices and affordability of the World Health Organization's essential medicines for children in Guatemala. Globalization and Health 2012 8:22.

\section{Submit your next manuscript to BioMed Central and take full advantage of:}

- Convenient online submission

- Thorough peer review

- No space constraints or color figure charges

- Immediate publication on acceptance

- Inclusion in PubMed, CAS, Scopus and Google Scholar

- Research which is freely available for redistribution 